\title{
Cytotoxicity and DNA protective effects of the Terfezia and Picoa species from the eastern region of Turkey
}

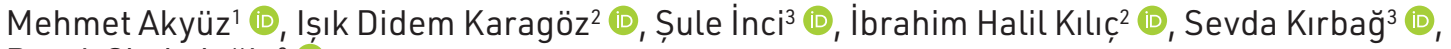 \\ Bașak Simitçioğlu² (i) \\ 'Bitlis Eren University, Science \& Arts Faculty, Department of Biology, Bitlis, Turkey \\ ${ }^{2}$ Gaziantep University, Science \& Arts Faculty, Department of Biology, Gaziantep, Turkey \\ ${ }^{3}$ Fırat University, Science Faculty, Department of Biology, Elazığ, Turkey
}

ORCID IDs of the authors: M.A. 0000-0003-3986-3498; I.D.K. 0000-0001-6527-2750; S.I. 0000-0002-4022-5269;

i.H.K. 0000-0002-0272-5131; S.K. 0000-0002-4337-8236; B.S. 0000-0002-2678-569X

Cite this article as: Akyuz, M., Karagoz, I. D., Inci, S., Kilic, I. H., Kirbag, S., \& Simitcioglu, B. (2021). Cytotoxicity and DNA protective effects of the Terfezia and Picoa species from the eastern region of Turkey. İstanbul Journal of Pharmacy, 51 (2), $198-203$.

\begin{abstract}
Background and Aims: This study aims to investigate the cytotoxicity and DNA protective effects of semi-arid, arid, or desert truffles such as the Terfezia and Picoa species.

Methods: The DNA protective effects of the Terfezia and Picoa species was evaluated using plasmid pBR322 DNA treated with $\mathrm{UV}$ and $\mathrm{H}_{2} \mathrm{O}_{2}$. The cytotoxic effects of water and methanol extracts of the Terfezia and Picoa species on $\mathrm{H} 1299$ and HUVEC cells were evaluated using the MTT assay.

Results: Higher concentrations of $T$. olbiensis and $P$. lefebvrei extracts have demonstrated a DNA protective effect. The water extract of $P$. juniperi only at a $40 \mathrm{mg} / \mathrm{mL}$ concentration demonstrated a DNA-protective effect, whereas $T$. boudieri extract did not show any DNA-protective effect at all concentrations tested. $\mathrm{H} 1299$ cells showed more sensitivity to the water extract of T. olbiensis (4.66\%), P. juniperi (12.04\%), P. lefebvrei (21.93\%), and the methanol extract of T. boudieri (20.93\%). In general, the water and methanol extracts of the Terfezia and Picoa species demonstrated the least cytotoxic effects on HUVEC cells, except for the water extract of $P$. juniperi (38.46\%).

Conclusions: In conclusion, results obtained from this study show that the Terfezia and Picoa truffle species have potential DNA protective and cancer prevention properties.

Keywords: arid-semi arid truffle, DNA protective activity, cytotoxicity effect, mushroom, Terfezia, Picoa
\end{abstract}

\section{INTRODUCTION}

Several studies have reported that food components and a balanced diet play a key role in maintaining human health integrity; however, when imbalanced, it can cause many chronic diseases (Ames, 2010). Despite extensive advances in treatment development over the past decade, the global prevalence of various diseases, cancer incidence, and the cancer-related mortality rate remain high (Ferlay et al., 2012; Torre et al., 2015). Genetic predisposition, sedentary lifestyle, poor dietary habits, diabetes, alcohol consumption, smoking, and other various external factors significantly increase the risk of developing various cancer types such as tumors of the liver, pancreas, lung, cervical, prostate, colorectal, skin, and breast (DeSantis et al., 2014; Siegel, Miller, \& Jemal, 2016; Sheikh, Sarker, Kamarudin, \& Ismail, 2017).

Some mushrooms species are edible for humans and can be used as dietary supplements. Not only the quality of their taste but also their biological properties are of significant value. Truffles are rich in many nutritional compounds such as protein, 
unsaturated fatty acids, carbohydrates, mineral substances, vitamins, amino acids, acids, dietary fibers, volatile organic compounds (Corrêa, Brugnari, Bracht, Peralta, \& Ferreira, 2016; Ma et al., 2018). Mushrooms are also known as a significant source of biologically active compounds such as glycoproteins, betaglucans, lectins, peptides, polysaccharides, vitamins, phenolic and polyphenolics, terpenoids, alcohols, and ergosterols. In the past thirty years, isolation of these compounds from various macrofungi has been performed and investigated as therapeutic agents in several studies (Aprotosoaie et al., 2017; Reis, Martins, Vasconcelos, Morales, \& Ferreira, 2017). These biomolecules of epigeous mushrooms are thought to be responsible for the biological and medicinal activities such as antioxidant (Özyürek, Bener, Güçlü, \& Apak, 2014; Souilem et al., 2017; Akyüz, Kireçci, Gökçe, Kirbağ, \& Yilmaz, 2019), detoxification, antigenotoxic, anticancer, angiostatic, radical scavenging, DNA protective (Kim \& Kim, 1999; Shameem, Kamili, Ahmad, Masoodi, \& Parray, 2017), antiviral, antimicrobial, antiparasitic, antifungal, antiinflammatory, hypoglycemic, cardiovascular, hypocholesterolemic, antihypertensive, hepatoprotective and immunomodulatory, as well as cytotoxicity effects on cancer cells (Wasser \& Weis 1999; Roupas, Keogh, Noakes, Margetts, \& Taylor, 2012; Souilem et al., 2017; Kothari, Patel, \& Kim, 2018). Furthermore, the most common uses of edible fungi are for the treatment of fatigue resistance, low immunity, microbial infection, heart disease, stroke, hypertension, diabetes, obesity, fatty liver, ageing, tumors, Parkinson and Alzheimer diseases (Valverde, Hernández-Pérez, \& Paredes-López, 2015).

Among all edible mushrooms, truffles show some distinctive characteristics and recently received more attention than other epigeous mushrooms. Truffles are one of the oldest types of food and are consumed in large quantities because of their incredibly delicious taste and musky aroma (Wang \& Marcone, 2011; Kagan-Zur, Roth Bejerano, Sitrit, \& Morte, 2014; Dahham, Al-Rawi, Ibrahim, Majid, \& Majid, 2018; Khalifa et al., 2019). The most commonly consumed truffles are the Terfezia, Tuber, and Tirmania species. They can be classified under two broad types: forest (Tuber) and arid, semi-arid, or desert truffles (Terfezia, Tirmania, and Picoa). Truffles are very rich in antioxidant compounds and can eliminate free radicals such as DPPH, ROS, and hydroxyl (OH) groups (Guo, Wei, Sun, Hou, \& Fan, 2011; Beara et al., 2014; Ferlay et al., 2015; Patel, Rauf, Khan, Khalid, \& Mubarak, 2017). Organisms have developed antioxidant defense and repair systems to protect their cellular environment from oxidative stress; however, these systems are insufficient to prevent damage completely (Wasser, 2011; Wasser, 2014; Sánchez, 2017). Therefore, antioxidant supplements or foods containing antioxidants can be used to help reduce the oxidative stress in the human body (Tadhani, Patel, \& Subhash, 2007). Antioxidant compounds can eliminate free radicals. Various compounds such as vitamins, carotenoids, proteins, peptides, phenolic compounds, nucleotides, polysaccharides, alkaloids and organic acids have been reported to have antioxidant activities (Sarmadi \& Ismail, 2010; Stajic, Vukojevic, Knezevic, Duletic Lausevic, \& Milovanovic, 2013).

DNA protective properties and cytotoxicity effects of the Ascomycetes (Terfezia and Picoa) species grown in the eastern region of Turkey are not well investigated because truffles have received less attention than epigeous fungi. Our aim in the present study is to investigate the cytotoxic effects and DNA protective properties of the Terfezia and Picoa species.

\section{MATERIALS AND METHODS}

\section{Truffle sample preparation}

The samples used in this study were obtained from previous work (Akyüz, Kırbağ, Bircan, \& Gürhan, 2015). The Terfezia and Picoa species were collected from Malatya (Central, Kale, Battalgazi, Arguvan Districts and theirs vicinity) and Elazığ (Baskil district and its vicinity), Turkey (N 38 19'- 43' E $038^{\circ} 19^{\prime}$ '- 51' with an altitude of 690-1375 m, the beginning of March to the end of May (rarely continue until mid-July). The samples were dried and sieved at room temperature, weighed $(30 \mathrm{~g}$ each), and placed in the cartridges of the Soxhlet instrument (Gerhardt EV 14). Extraction was performed for $3 \mathrm{~h}$ in $150 \mathrm{~mL}$ methanol (Merck) and $\mathrm{dH}_{2} \mathrm{O}$ separately in the Soxhlet device. Then, the solvents were removed by an evaporator device. The extracts obtained were stored at $+4 \mathrm{C}$. The day after extraction, studies were started with fresh extracts.

\section{Evaluation of the DNA protective effect}

The evaluation of the protective effect of the extracts on DNA damage was performed using the screening of plasmid DNA pBR322 (Vivantis) treated with UV and $\mathrm{H}_{2} \mathrm{O}_{2}$ in gel electrophoresis. Plasmid DNA's are widely used in DNA protective activity determination and give reliable results (Golla \& Bhimathati, 2014; Verma, Shrivastava, \& Kumar, 2015; Soumya et al., 2019). In the study, plasmid DNA samples were treated with the extracts, oxidized by $\mathrm{H}_{2} \mathrm{O}_{2}+\mathrm{UV}$ treatment, and then, checked on $1.25 \%$ agarose gels, according to Russo et al. (2000). Each tube of the experimental samples contained $3 \mu \mathrm{L}$ pBR322 plasmid DNA $(172 \mathrm{ng} / \mu \mathrm{L}), 1 \mu \mathrm{L}$ of $30 \% \mathrm{H}_{2} \mathrm{O}_{2}$, and $5 \mu \mathrm{L}$ of each extract at $40,20,10$, and $5 \mathrm{mg} / \mathrm{mL}$ in a total volume of $10 \mu \mathrm{L}$. UV irradiation continued for five minutes on a UV transilluminator (DNR-IS) surface with an intensity of $8 \mathrm{~mW} / \mathrm{cm}^{2}$ at $302 \mathrm{~nm}$ at room temperature. After irradiation, $10 \mu \mathrm{L}$ of the reaction mixture were mixed with loading dye (6x) and loaded on a 1.25\% agarose gel for electrophoresis. Untreated pBR322 plasmid DNA and partially treated plasmids with only UV or only $\mathrm{H}_{2} \mathrm{O}_{2}$ were used as controls in each run of gel electrophoresis. Gels were stained with EtBr and photographed using the gel documentation system (DNR-IS, MiniBIS Pro) (Tepe, Degerli, Arslan, Malatyali, \& Sarikurkcu, 2011).

\section{Cell lines}

H1299 (non-small cell lung cancer) and HUVEC (Human umbilical vein endothelial cell) cell lines were grown in the DMEM (Dulbecco's Modified Eagle Medium) (Gibco, USA) supplemented with 10\% fetal bovine serum (FBS), 1\% antibiotic solution (100 U/ $\mathrm{mL}$ penicillin and $100 \mu \mathrm{g} / \mathrm{mL}$ streptomycin) and then incubated at $37{ }^{\circ} \mathrm{C}$ in $5 \% \mathrm{CO}_{2}$ humidified incubator (Jin, Zhang, Kang, Wang, \& Zhao, 2010). Cells were counted with a hemocytometer and diluted to the cell density required for the MTT assay.

\section{The Cytotoxic activity assay}

The cell viabilities of H1299 and HUVEC cell lines treated with various concentrations of extracts were evaluated using the 
MTT assay. The MTT assay is a highly preferred method for determining cytotoxic activity. The MTT dye is a yellow colored compound which is reduced by mitochondrial dehydrogenase produced by the live cells to water insoluble blue colored formazan crystals. When formazan crystals dissolve, it gives absorbance at $570 \mathrm{~nm}$ in the spectrophotometer (Mosmann, 1983). Firstly, $5 \times 10^{3}$ cells/well were seeded in a 96 well-plate. After 24 hours, truffle extracts were added to cells at the concentrations of $6.25,12.5,25,50,100 \mu \mathrm{g} / \mathrm{mL}$ ). Forty-eight hours later, the MTT solution was added and the cells were incubated at $37^{\circ} \mathrm{C}$ and $5 \% \mathrm{CO}_{2}$ for four hours. Then, DMSO was added to each well to dissolve the formed formazan crystals. The color intensity was measured using a spectrophotometer at a wavelength of $570 \mathrm{~nm}$. Viability (\%) of cells were calculated using absorbance readings (Berridge, Herst, \& Tan, 2005). A statistical calculation was made with the Graphpad Prism program with nonlinear regression analysis and graphs were created. Also, the relative cell viability was calculated using the following formula: Viable cells (\%) $=\left(\right.$ As/Ac) ${ }^{*} 100$ (As: Absorbance of extraction treated sample cells, Ac: Absorbance of the control cell group).

\section{RESULTS}

The DNA protective effects of water extracts obtained from desert truffle on pBR322 plasmid DNA were evaluated. The DNA protective activity of these extracts as shown in Figure 1. The DNA protective effects of five different concentrations of water extracts obtained from the Terfezia and Picoa species were evaluated using the plasmid pBR322 DNA screening method in gel electrophoresis. The DNA derived from plasmid pBR322 showed three bands in agarose gel electrophoresis. The faster-moving band on the gel is scDNA, and the slower-moving band is ocDNA and linDNA, which is the result of the separation of the open-circular DNA (Figure 1, Lane 1-3). These bands were stable in the presence of UV and $\mathrm{H}_{2} \mathrm{O}_{2}$ at the four different concentrations of water extracts obtained from the Terfezia and Picoa species (Figure 1, Lane 4-19).

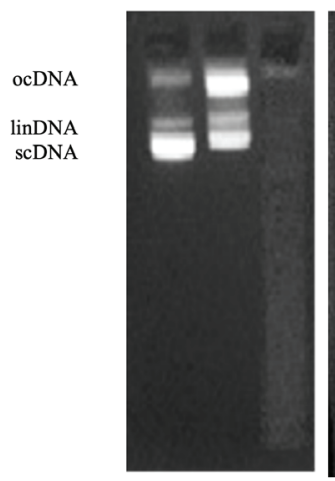

Lane 1-3

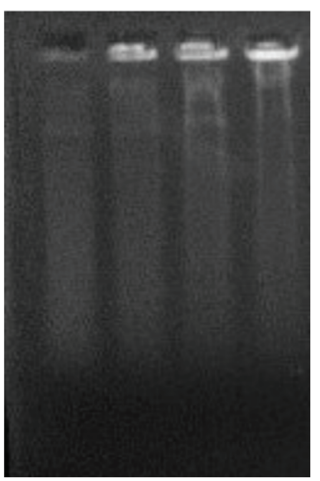

Lane 4-7

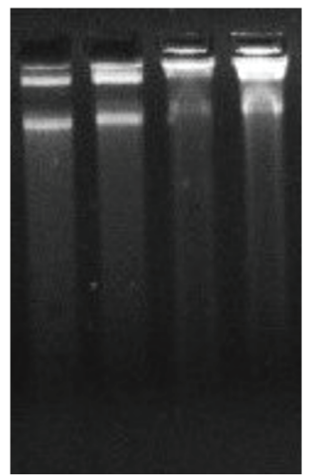

Lane 8-11

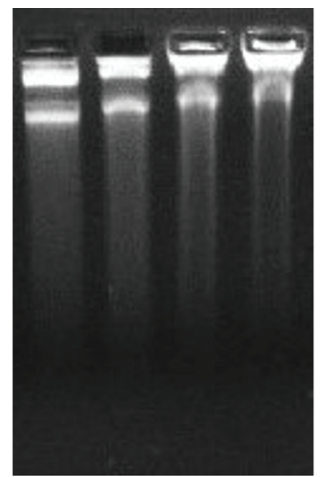

Lane 12-15

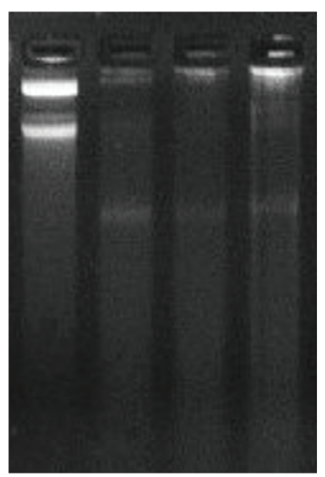

Lane 16-19

Figure 1. Electrophoretic pattern of pBR322 plasmid DNA after treatment with $\mathrm{dH}_{2} \mathrm{O}, \mathrm{UV}$ and $\mathrm{H}_{2} \mathrm{O}_{2}$ in the presence of water extracts. Lane 1: Plasmid DNA $(3 \mu \mathrm{L})+\mathrm{dH}_{2} \mathrm{O}(6 \mu \mathrm{L})$, Lane 2: Plasmid DNA $(3 \mu \mathrm{L})+\mathrm{dH}_{2} \mathrm{O}(6 \mu \mathrm{L})+\mathrm{UV}$, Lane 3: Plasmid DNA $(3 \mu \mathrm{L})+\mathrm{dH}_{2} \mathrm{O}(6 \mu \mathrm{L})+\mathrm{H}_{2} \mathrm{O}_{2}(1 \mu \mathrm{L})+\mathrm{UV}$, Lane 4-7: Plasmid DNA $(3 \mu \mathrm{L})+40,20,10$ and $5 \mathrm{mg} / \mathrm{mL}$ of T. boudieri water extracts $+\mathrm{UV}+\mathrm{H}_{2} \mathrm{O}_{2}(1 \mu \mathrm{L})$, Lane 8-11: Plasmid DNA $(3 \mu \mathrm{L})+40,20,10$ and $5 \mathrm{mg} / \mathrm{mL}$ of T. olbiensis water extracts $+\mathrm{UV}+\mathrm{H}_{2} \mathrm{O}_{2}(1 \mu \mathrm{L})$, Lane 12-15: Plasmid DNA $(3 \mu \mathrm{L})+40,20,10$ and $5 \mathrm{mg} / \mathrm{mL}$ of $P$. lefebvrei water extracts $+\mathrm{UV}+\mathrm{H}_{2} \mathrm{O}_{2}(1 \mu \mathrm{L})$, Lane 16-19: Plasmid DNA $(3 \mu \mathrm{L})+40,20,10$ and $5 \mathrm{mg} / \mathrm{mL}$ of P. juniperi water extracts $+\mathrm{UV}+\mathrm{H}_{2} \mathrm{O}_{2}(1 \mu \mathrm{L})$, respectively]. 

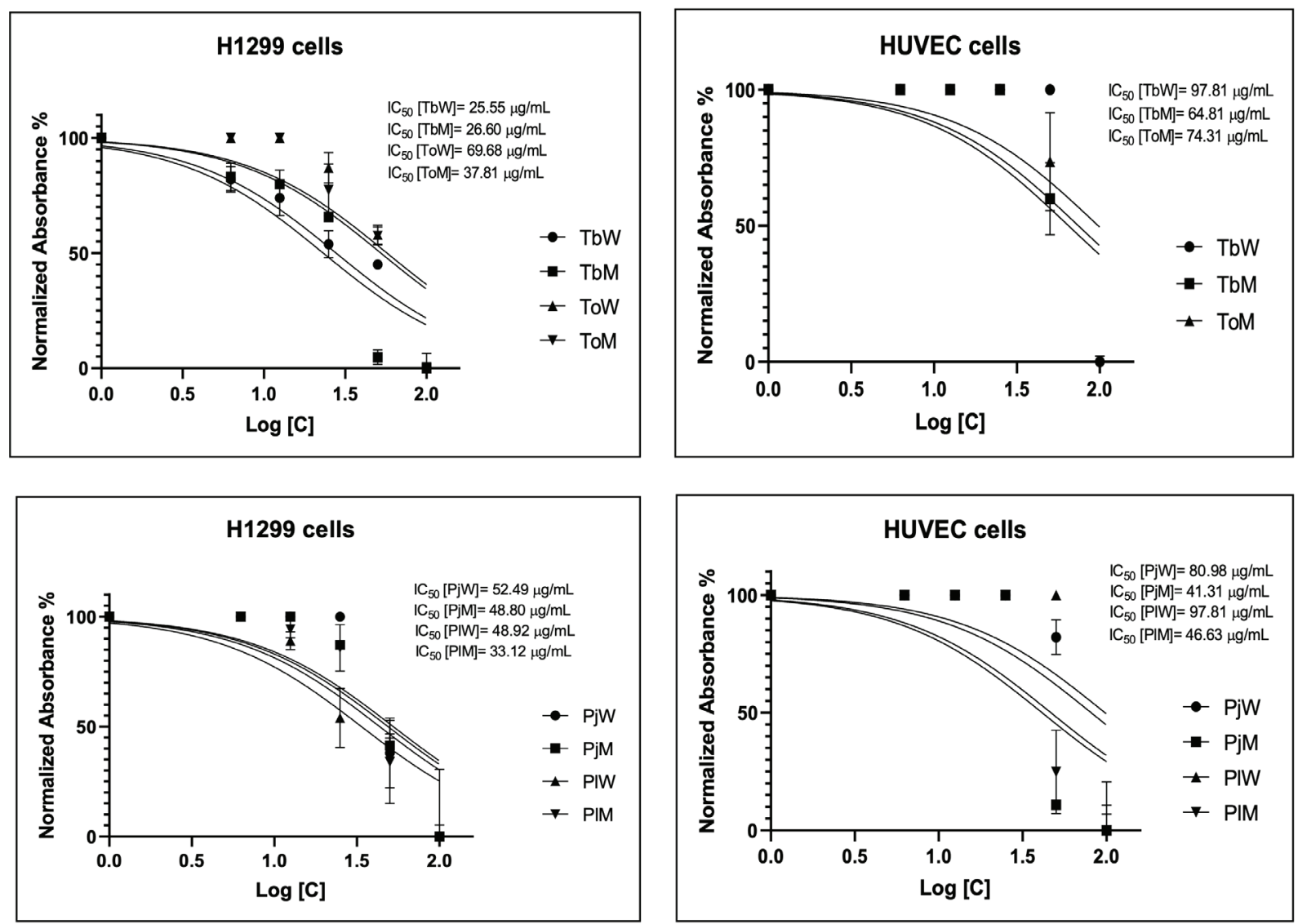

Figure 2. Normalized absorbances \% of Terfezia and Picoa extracts on H1299 and HUVEC cell lines. (W: water, M: methanol, Pj: P. juniperi, PI: P. lefebvrei, To: T. olbiensis, Tb: T. boudieri).

fects of $92.07 \%, 62.28 \%$, and $36.09 \%$ at 25,50 , and $100 \mu \mathrm{g} / \mathrm{mL}$, respectively. The water extract from $P$. lefebvrei did not show any cytotoxicity on $\mathrm{H} 1299$ cell line at a concentration of 6.25 $\mathrm{\mu g} / \mathrm{mL}$; however, it showed cytotoxic effects of $99.46 \%$ at 12.5 $\mu \mathrm{g} / \mathrm{mL}, 64.32 \%$ at 25 and $50 \mu \mathrm{g} / \mathrm{mL}$, and $21.93 \%$ at $100 \mu \mathrm{g} / \mathrm{mL}$. The methanol extract of $P$. lefebvrei at a concentration of 6.25 $\mathrm{\mu g} / \mathrm{mL}$ did not show any cytotoxic effect on the same cell line; however, it showed cytotoxic effects of 97.26\%, 97.15\% 55.06\% and $42.41 \%$ at $12.5,25,50$, and $100 \mu \mathrm{g} / \mathrm{mL}$, respectively.

The water extract of $T$. boudieri showed no cytotoxic effect on HUVEC cell line at the concentrations of 6.25, 12.5, 25 and 50 $\mathrm{\mu g} / \mathrm{mL}$; however, it showed a cytotoxic effect $96.02 \%$ at 100 $\mu \mathrm{g} / \mathrm{mL}$. The methanol extract did not show any effect on cell viability at the concentrations of $6.25,12.5$ and $25 \mu \mathrm{g} / \mathrm{mL}$ on the same cell line; however, it showed a cytotoxic effect of $98.9 \%$ and $69.77 \%$ at 50 , and $100 \mu \mathrm{g} / \mathrm{mL}$, respectively. The water extract of T. olbiensis had no cytotoxic effect on HUVEC cell line at the concentrations of $6.25,12.5,25,50$ and $100 \mu \mathrm{g} / \mathrm{mL}$. The methanol extract of T. olbiensis had no cytotoxic effect on HUVEC cell line at the concentrations of 6.25, 12.5 and $25 \mu \mathrm{g} /$ $\mathrm{mL}$; however, it showed cytotoxic effects of $95.82 \%$ and $67.31 \%$ at 50 , and $100 \mathrm{\mu g} / \mathrm{mL}$, respectively. The water extract of P. juniperi on HUVEC cell line did not show any effect on cell viability at concentrations of 6.25 and $12.5 \mu \mathrm{g} / \mathrm{mL}$, however it showed cytotoxic effects of $98.89 \%, 96.39 \%$ and $38.46 \%$ at 25,50 , and $100 \mathrm{\mu g} / \mathrm{mL}$. The methanol extract showed no cytotoxicity on the same cell line at $6.25,12.5$, and $25 \mu \mathrm{g} / \mathrm{mL}$, while it showed cytotoxic effects of $83.02 \%$ and $62.28 \%$ at 50 and $100 \mu \mathrm{g} / \mathrm{mL}$. There was no cytotoxic effect of water and methanol extracts obtained from P. lefebvrei on $\mathrm{H} 1299$ cell line at the concentrations of $6.25,12.5$, and $25 \mu \mathrm{g} / \mathrm{mL}$. The water extract showed a cytotoxic effect of $87.22 \%$ and $64.32 \%$ at 50 and $100 \mu \mathrm{g} / \mathrm{mL}$, respectively on the same cell line, while the methanol extract showed a cytotoxic effect of $85.17 \%$ and $55.14 \%$ at 50, and 100 $\mu \mathrm{g} / \mathrm{mL}$, respectively (Figure 2).

\section{DISCUSSION}

Several studies have demonstrated the antiangiogenic, antimetastatic, chemopreventive, antitumor, antiproliferative, and neo-adjuvant properties of traditional medicinal plants in vitro, in vivo and in various clinical cancer models (Roupas et al., 2012; Siegel et al., 2016; Kothari et al., 2018; Khalifa et al., 2019). Many diseases, such as neurodegenerative diseases and cancer, arise as a result of the imbalance between oxidant and antioxidant defense mechanisms. Previous studies (Kim \& Kim 1999; Guo et al., 2011; Beara et al., 2014; Xiao et al., 2015; Aprotosoaie et al., 2017; Shameem et al., 2017) have reported that these diseases are responsible for oxidative DNA damage caused by ROS, such as superoxide anion, hydroxyl radical and hydrogen peroxide. In the present study, results showed that all concentrations of water extracts obtained from T. olbiensis and P. lefebvrei, and the 40 $\mathrm{mg} / \mathrm{mL}$ concentration of $P$. juniperi protected the ocDNA band 
of pBR322 plasmid DNA. Some mushrooms can protect cellular DNA from oxidative damage. It has been suggested that antioxidant properties of fungi can be identified by various oxidation process stages and by different mechanisms as mentioned by previous studies (Tadhani et al., 2007; Sarmadi \& Ismail, 2010; Wasser, 2011; Stajic et al., 2013; Wasser, 2014; Sánchez, 2017; Živković et al., 2019). Edible mushrooms can be proposed as a dietary supplement or traditional drug to confer prevention and/or treatment of conditions arising from oxidative damage. These edible fungi are also able to protect DNA from damage induced by hydroxyl, superoxide anion, and hydrogen peroxide radicals as reported by the previously mentioned studies. As a result, some edible mushrooms represent a valuable source of bio compounds with the potential to protect cellular DNA from oxidative damage in contrast to other mushroom species (Roupas et al., 2012). According to the data mentioned above, the DNA protective effect of both the Terfezia and Picoa species is strongly dependent on the truffle type and their origins. In this regard, our study results support the findings of the previously published studies, as mentioned above.

For evaluating the cytotoxic effect of the extracts, H1299 and HUVEC cell lines were used, which are the most relevant to perform cytotoxicity studies. The water extracts of T. olbiensis, P. juniperi, P. lefebvrei, and the methanol extract of T. boudieri has remarkably decreased the percentage of viability in H1299 cells. Intriguingly, the water extract of T. olbiensis at $100 \mu \mathrm{g} /$ $\mathrm{mL}$, in particular, showed a selective cytotoxic effect. The water and methanol extracts of the same species showed no strong cytotoxic effect on HUVEC cell line, however, the water extract of $P$. juniperi showed strong cytotoxic effect at $100 \mu \mathrm{g} /$ $\mathrm{mL}$. These results suggest that various species of Terfezia and Picoa have potent cytotoxicity effects on H1299 and HUVEC cell lines. Various solvent extracts such as aqueous, methanol, ethanol, hexane, ethyl acetate, and bioactive molecules such as polysaccharides, glucans, agaritine, cordycepin, ergosterol, triterpenes, polysaccharopeptides, lectin, lentinan, are extracted using multiple assays and techniques from the fruit bodies of various mushrooms such as Agaricus spp., G. lucidum, L. edodes, G. frondosa, Pleurotus spp., H. erinaceus, C. militaris, Tuber magnatum, T. aestivum, Terfezia claveryi and showed cytotoxic activities on MCF-7, SK-Hep1, A549, HepG2, L929, HeLa, HT-29, U-87 MG, PC3, T24 cells in a dose-dependent manner (Roupas et al., 2012; Beara et al., 2014; Souilem et al., 2017; Kothari et al., 2018; Dahham et al., 2018; Elsayed, Alsahli, El Enshasy, \& Wadaan, 2019). Therefore, dietary supplementation of edible mushroom extracts may serve as a potential antioxidant or immunity-boosting agent that helps in cancer prevention. Some Ascomycetes and Basidiomycetes are clinically used for the prevention and treatment of several diseases in some countries. The activity of these mushrooms is generally related to the presence of biomolecules, which are considered as biological response modifiers, as reported by the previously published studies. Various assays and techniques have been used to investigate the efficacy of the biologically active compounds in vitro, in vivo and in clinical trials. The results of the studies performed on fungi species in various cancer cell lines are quite different from each other as stated in the aforementioned studies. We think that these different results may depend on the species of fungi tested, sample preparation methods, the solvent used for extraction and the cancer cell line tested, various assays, techniques and analysis methods used, as shown in the above mentioned studies.

\section{CONCLUSION}

In conclusion, our findings suggest that the truffle (Terfezia and Picoa) species might contain some cytotoxic substances related to these metabolites. Given these results, the truffle (Terfezia and Picoa) species demonstrate potential DNA protective and cytotoxic activities, which may be responsible for their therapeutic effects. This study provides a useful basis for future studies on the DNA-protective and cancer-preventive properties of truffles.

Peer-review: Externally peer-reviewed.

Author Contributions: Concept- M.A., S.K.; Design- M.A.; SupervisionM.A.; I.D.K., Resource- M.A.; Materials- M.A., S.K.; Data Collection and/ or Processing- M.A., I.D.K., S.K.; Analysis and/or Interpretation- I.D.K., S.l., I.H.K., S.K., B.S.; Literature Search- M.A., S.K., I.D.K.; Writing- M.A., I.D.K.

Conflict of Interest: The authors have no conflict of interest to declare.

Financial Disclosure: The authors declared that this study has received no financial support.

\section{REFERENCES}

- $\quad$ Akyüz, M., Kırbağ, S., Bircan, B., \& Gürhan, Y. (2015). Diversity and distribution of arid semi arid truffle (Terfezia and Picoa) in ElazığMalatya region of Turkey. Mycosphere, 6, 766-783.

- $\quad$ Akyüz, M., Kireçci, A. D. Ö., Gökçe, Z., Kirbağ, S., \& Yilmaz, Ö. (2019). Biochemical constituents and antioxidant activities of some mushrooms from Turkey. Agaricus spp., Pleurotus spp., Morchella esculenta and Terfezia boudieri. Istanbul Journal of Pharmacy, 49, $1-6$.

- $\quad$ Ames, N. B. (2010). Prevention of mutation, cancer, and other ageassociated diseases by optimizing micronutrient intake. Journal of Nucleic Acids, 2010, 1-11.

- $\quad$ Aprotosoaie, A. C., Zavastin, D. E., Mihai, C. T., Voichita, G., Gherghel, D., Silion, M., \& Miron, A. (2017). Antioxidant and antigenotoxic potential of Ramaria largentii Marr \& DE Stuntz, a wild edible mushroom collected from Northea Romania. Food \& Chemical Toxicology, 108, 429-437.

- Beara, I. N., Lesjak, M. M., Četojević-Simin, D. D., Marjanović, Ž. S., Ristić, J. D., Mrkonjić, Z. O., \& Mimica-Dukić, N. M. (2014). Phenolic profile, antioxidant, anti-inflammatory and cytotoxic activities of black (Tuber aestivum Vittad) and white (Tuber magnatum Pico) truffles. Food Chemistry, 165, 460-466.

- $\quad$ Berridge, M. V., Herst, P. M., \& Tan, A. S. (2005). Tetrazolium dyes as tools in cell biology, new insights into their cellular reduction. Biotechnology Annual Review, 11, 127-152.

- Corrêa, R. C. G., Brugnari, T., Bracht, A., Peralta, R. M., \& Ferreira, I. C. (2016). Biotechnological, nutritional and therapeutic uses of Pleurotus spp. (Oyster mushroom) related with its chemical composition, A review on the past decade findings. Trends in Food Science \& Technology, 50, 103-117.

- Dahham, S. S., Al-Rawi, S. S., Ibrahim, A. H., Majid, A. S. A., \& Majid, A. M. S. A. (2018). Antioxidant, anticancer, apoptosis properties and chemical composition of black truffle Terfezia claveryi. Saudi Journal of Biological Science, 25, 1524-1534. 
- DeSantis, C. E., Lin, C. C., Mariotto, A. B., Siegel, R. L., Stein, K. D., Kramer, J. L., Alteri, R., Robbins, A. S., \& Jemal, A. (2014). Cancer treatment and survivorship statistics. CA Cancer Journal for Clinicians, 252-271.

- $\quad$ Elsayed, E. A., Alsahli, F. D., El Enshasy, H. A., \& Wadaan, M. A. (2019). Cytotoxic activities of different solvent extracts of Tirmania nivea and Terfezia claveryi against HepG2 and L929. Journal of Scientific \& Industrial Research, 78, 454-457.

- Ferlay, J., Soerjomataram, I., Dikshit, R., Eser, S., Mathers, C., Rebelo, M., Parkin, D. M., Forman, D., \& Bray, F. (2015). Cancer incidence and mortality worldwide, sources, methods and major patterns in Globocan 2012. International Journal of Cancer, 136, 359-386.

- Golla, U., Bhimathati, S. S. R. (2014). Evaluation of antioxidant and DNA damage protection activity of the hydroalcoholic extract of Desmostachya bipinnata L. Stapf. The Scientific World Journal, 2014, $1-8$.

- $\quad$ Guo, T., Wei, L., Sun, J., Hou, C. L., \& Fan, L. (2011). Antioxidant activities of extract and fractions from Tuber indicum Cooke \& Massee. Food Chemistry, 127, 1634-1640.

- Jin, S., Zhang, Q. Y., Kang, X. M., Wang, J. X. \& Zhao, W. H. (2010). Daidzein induces MCF-7 breast cancer cell apoptosis via the mitochondrial pathway. Annals of Oncology, 21, 263-268.

- Kagan-Zur, V., Roth Bejerano, N., Sitrit, Y., \& Morte, A. (2014). Desert truffle (phylogeny, physiology, distribution and domestication), Springer Verlag Berlin Heidelberg.

- $\quad$ Khalifa, S. A. M., Farag, M. A., Yosrie, N., Sabir, J. S. M., Saeed, A., AlMousawi, S. M., Taha, W., Musharraf, S. G., Patel, S., \& El-Seedi, H. R. (2019). Truffles, from Islamic culture to chemistry, pharmacology, and food trends in recent times Trends in Food Science \& Technology, 91, 193-218.

- Kim, K. C., \& Kim, I. G. (1999). Ganoderma lucidum extract protects DNA from strand breakage caused by hydroxyl radical and UV irradiation. International Journal of Molecular Medicine, 4, 273-280.

- Kothari, D., Patel, S., \& Kim, S. K. (2018). Anticancer and other therapeutic relevance of mushroom polysaccharides, A holistic appraisal. Biomedicine \& Pharmacotherapy, 105, 377-394.

- Ma, G., Yang, W., Zhao, L., Pei, F., Fang, D., \& Hu, Q. (2018). A critical review on the health promoting effects of mushrooms nutraceuticals. Food Science and Human Wellness, 7, 125-133.

- Mosmann, T. (1983). Rapid colorimetric assay for cellular growth and survival: Application to proliferation and cytotoxicity assays. Journal of Immunological Methods, 65, 55-63.

- Özyürek, M., Bener, M., Güçlü, K., \& Apak, R. (2014). Antioxidant/ antiradical properties of microwave-assisted extracts of three wild edible mushrooms. Food Chemistry, 157, 323-331.

- $\quad$ Patel, S., Rauf, A., Khan, H., Khalid, S., \& Mubarak, M. S. (2017). Potential health benefits of natural products derived from truffles, a review. Trends in Food Science \& Technology, 70, 1-8.

- Reis, F. S., Martins, A., Vasconcelos, M. H., Morales, P., \& Ferreira, I. C. (2017). Functional foods based on extracts or compounds derived from mushrooms. Trends in Food Science \& Technology, 66, 48-62.

- $\quad$ Roupas, P., Keogh, J., Noakes, M., Margetts, C., \& Taylor, P. (2012). The role of edible mushrooms in health, Evaluation of the evidence. Journal of Functional Foods, 4, 687-709.

- Russo, A., Acquaviva, R., Campisi, A., Sorrenti, V., Di-Giacomo, C., Virgata, G., Barcellona, M. L., \& Vanella, A. (2000). Bioflavonoids as antiradicals, antioxidants and DNA cleavage protectors. Cell Biology \& Toxicology, 16, 91-98.

- Sánchez, C. (2017). Reactive oxygen species and antioxidant properties from mushrooms. Synthetic \& Systems Biotechnology, $2,13-22$.
Sarmadi, B. H., \& Ismail, A. (2010). Antioxidative peptides from food proteins, a review. Peptides, 31, 1949-1956.

Shameem, N., Kamili, A. N., Ahmad, M., Masoodi, F. A., \& Parray, J. A. (2017). Radical scavenging potential and DNA damage protection of wild edible mushrooms of Kashmir Himalaya. Journal of the Saudi Society of Agricultural Sciences, 16, 314-321.

- Sheikh, B. Y., Sarker, M. M. R., Kamarudin, M. N. A., \& Ismail, A. (2017). Prophetic medicine as potential functional food elements in the intervention of cancer, A review. Biomedicina \& Pharmacotherapy, 95, 614-648.

- $\quad$ Siegel, R. L., Miller, K. D., \& Jemal, A. (2016). Cancer statistics. CA Cancer Journal for Clinicians, 66, 7-30.

Souilem, F., Fernandes, Â., Calhelha, R. C., Barreira, J. C., Barros, L., Skhiri, F., \& Ferreira, I. C. (2017). Wild mushrooms and their mycelia as sources of bioactive compounds, antioxidant, anti-inflammatory and cytotoxic properties. Food Chemistry, 230, 40-48.

Soumya, K., Haridas, K. R., James, J., Kumar, V. B. S., Edatt, L., Sudheesh, S. (2019). Study of in vitro antioxidant and DNA damage protection activity of a novel luteolin derivative isolated from Terminalia chebula. Journal of Taibah University for Science, 13, 755-763.

- Stajic, M., Vukojevic, J., Knezevic, A., Lausevic, S. D., \& Milovanovic, I. (2013). Antioxidant protective effects of mushroom metabolites. Current Topics in Medicinal Chemistry, 13, 2660-2676.

- Tadhani, M. B., Patel, V. H., \& Subhash, R. (2007). In vitro antioxidant activities of Stevia rebaidiana leaves and callus. Journal of Food Composition \& Analysis, 20, 323-329.

- $\quad$ Tepe, B., Degerli, S., Arslan, S., Malatyali, E., \& Sarikurkcu, C. (2011). Determination of chemicalprofile, antioxidant, DNA damage protection and ant amoebic activities of Teucrium polium and Stachy siberica. Fitoterapia, 82, 237-246.

- Torre, L. A., Bray, F., Siegel, R. L., Ferlay, J., Lortet-Tieulent, J., \& Jemal, A. (2012). Global cancer statistics. Cancer Journal for Clinicians, 65, 87-108.

- Valverde, M. E., Hernández-Pérez, T., \& Paredes-López, O. (2015). Edible mushrooms: improving human health and promoting quality life. International Journal of Microbiology, 2015, 1-14.

Verma, K., Shrivastava, D., \& Kumar, G. (2015). Antioxidant activity and DNA damage inhibition in vitro by amethanolic extract of Carissa carandas (Apocynaceae) leaves. Journal of Taibah University for Science, 9, 34-40.

- Wang, S., \& Marcone, M. F. (2011). The biochemistry and biological properties of the world's most expensive underground edible mushroom, Truffles. Food Research International, 44, 2567-2581.

Wasser, S. P. (2011). Current findings, future trends, and unsolved problems in studies of medicinal mushrooms. Applied Microbiology \& Biotechnology, 89, 1323-1332.

- Wasser, S. P. (2014). Medicinal mushroom science, current perspectives, advances, evidences, and challenges. Biomedical Journal, 37, 345-356.

- Wasser, S. P., \&Weis, A. L. (1999). Medicinal properties of substances occurring in higher basidiomycetes mushrooms, current perspective (review). International Journal of Medicinal Mushrooms, 1, 31-62. Xiao, Y., Zhang, Q., Miao, J., Rui, X., Li, T. \& Dong, M. (2015). Antioxidant activity and DNA damage protection of mung beans processed by solid state fermentation with Cordyceps militaris SN18. Innovative Food Science \& Emerging Technologies, 31, 216-225. Živković, L., Bajić, V., Bruić, M., Borozan, S., Popić, K., Topalović, D., \& Spremo- Potparević, B. (2019). Antigenotoxic and antioxidant potential of medicinal mushrooms (Immune Assist) against DNA damage induced by free radicals-an in vitro study. Mutation Research Genetic Toxicology \& Environmental Mutagenesis, 845, 403078 